\title{
Seric status of vitamin $D$ among nulligest women at the general reference hospital of Panzi in Democratic Republic of the Congo
}

\author{
Sifa Balungwe ${ }^{1 *}$, Raha Maroyi ${ }^{1}$, Mpakanyi Joyeux ${ }^{1}$, Mukango Omari², Mulongo Philémon, \\ Nakiyo Olivier ${ }^{3}$
}

\author{
${ }^{1}$ Department of Obstetrics and Gynecology, Panzi Hospital, Bukavu, Democratic Republic of The Congo \\ ${ }^{2}$ Independent Consultant, Bukavu, Democratic Republic of The Congo \\ ${ }^{3}$ Department of Midwifery, ISTM-Bukavu, Bukavu, Democratic Republic of The Congo
}

Received: 25 January 2021

Revised: 07 March 2021

Accepted: 08 March 2021

\section{*Correspondence:}

Dr. Sifa Balungwe,

E-mail: sifabalu@gmail.com

Copyright: (C) the author(s), publisher and licensee Medip Academy. This is an open-access article distributed under the terms of the Creative Commons Attribution Non-Commercial License, which permits unrestricted non-commercial use, distribution, and reproduction in any medium, provided the original work is properly cited.

\begin{abstract}
Background: Vitamin D has both bony and extra bony implications. The objective of this study was to determine serum vitamin D levels in non-breastfeeding women aged 20 to 35 years.

Methods: A cross-sectional study was conducted at the Panzi General Reference Hospital in the Democratic Republic of Congo (DRC) with an occasional sample of 412 nulligest women sensitized during gynecological consultations. A vitamin D test was performed using the immunofluorescence technique and a trans-abdominal ultrasound was routinely performed. Vitamin D deficiency was defined by a serum level $\leq 29 \mathrm{ng} / \mathrm{dl}$. Data were collected using a pre-established survey questionnaire.

Results: The mean age of the women was $25.23 \pm 4.54$ years. The serum vitamin D level was $77.2 \%$ too high, indicating vitamin D deficiency in our context. The nulliparous, students and overweight women were the most encountered. Women who consumed more red meat, green vegetables and alcohol were more affected. Pelvic pain, pelvic pain and bleeding between periods dominated the clinical picture.

Conclusions: The serum level was very high in nulligest women aged 20 to 35 years. The study recommends expanded screening and vitamin D supplementation for the prevention of myomas and other conditions in nulligest women.
\end{abstract}

Keywords: Serum levels, Vitamin D deficiency, Nulliparous, HGRP

\section{INTRODUCTION}

In Western countries, more than $40 \%$ of the population over 50 years of age is said to be deficient in vitamin D. In Europe, a study showed that $80 \%$ of elderly people had levels of $25(\mathrm{OH}) \mathrm{D}$ below $30 \mathrm{ng} / \mathrm{ml} .^{1,2}$

In France, the prevalence of deficient people varies greatly between the south and the north of the country. The percentage of people with severe deficiency with levels of
25(OH) D below $8 \mathrm{ng} / \mathrm{ml}(20 \mathrm{nmol} / \mathrm{l})$ increases from $7 \%$ on the French Riviera to $29 \%$ in the North. ${ }^{3}$

The decrease in cholecalciferol synthesis (the most frequent cause), low sun exposure (latitude, season, clothing (veiled woman), use of sunscreen creams, dark phototype, insufficient dietary intake, increased catabolism, obesity (fat sequestration) and renal losses. ${ }^{4-6}$

It is considered that vitamin D cannot be synthesized by sun exposure during some winter months. Dark skin 
requires an increase in sun exposure time of three to five times. A sunscreen with an index of 30 reduces synthesis by more than $95 \%$.

In Africa, few studies are done and in Democratic Republic of Congo (DRC) a study was carried out in 2016, vitamin $\mathrm{D}$ deficiency was observed in $17.1 \%$ of women without uterine myomas and in $47.7 \%$ of women with uterine myomas. Research has shown in vitro that vitamin D $(25(\mathrm{OH}) \mathrm{D})$ can inhibit the proliferation of uterine leiomyomas. ${ }^{6,7}$ The active metabolite of vitamin $\mathrm{D}$ has been shown to inhibit cell proliferation and extracellular matrix production in fibrous tissue culture and reduce the volume of fibroids in Esker rats. ${ }^{7,8}$ It is questionable whether there is a preventive interest of this supplementation not only in the prevention of early onset of myomas but also in a protective role in other pathologies.

In the gynecology department at the Panzi General Referral Hospital, we found an early onset of uterine myomas in nulligestes between 20 and 35. However, we do not have a consensus on the dosage of vitamin $\mathrm{D}$ and supplementation of vitamin D deficiency in this population. We thought it would be interesting to conduct a study on vitamin D insufficiency and deficiency in nulligestes between 20 and 35 years old in South Kivu. This study is intended to provide a basis for reflection on the interest of dosing and supplementation of vitamin D insufficiency or deficiency in this population. Considering the consequences of vitamin D deficiency and their cost at the global level, research on this subject is indispensable. The objective of this study is to determine serum vitamin D levels among nulligest women aged 20 to 35 years in South Kivu.

\section{METHODS}

This cross-sectional study was conducted in South Kivu, at the General Referral Hospital of Panzi, among nulligestes during the period from 01 August 2017 to 01 August 2019. The selection of nulligest women was occasional after their informed consent. The women participating in the study were sensitized at the Gynecology and Obstetrics Department of Panzi Hospital. Nulligest women aged 20 to 35 years were selected who did not present any major health problems interfering with vitamin D metabolism. The criterion for inclusion in the study was their agreement to the collection and completion of the survey questionnaire. The samples were anonymized and sent to the laboratory at Panzi Hospital for testing. Exclusion criteria for the study were all chronic conditions that cause hypovitaminosis or treatments that interfere with vitamin D metabolism. All assays were performed by the Panzi Hospital laboratory using dry-tube serum from the nulligestes. The element measured was 25 $(\mathrm{OH})$ vitamin D (D2 and D3). The serum vitamin D assay was based on the principle of Immunofluorescence. The technique allows the determination of D2 and D3 forms.

The detection limit for low values was $10 \mathrm{ng} / \mathrm{ml}$; the measuring range of the assay was 8 to $160 \mathrm{ng} / \mathrm{ml}$.

The reproducibility of the test used was of thresholds used - deficiency: serum concentration $\leq 20 \mathrm{ng} / \mathrm{ml}$; deficiency: serum concentration between 20 and $29 \mathrm{ng} / \mathrm{ml}$; and normal value: serum concentration greater than $30 \mathrm{ng} / \mathrm{ml}$. Then vitamin D deficiency was defined by a serum level $\leq 29$ $\mathrm{ng} / \mathrm{dl}$. The data collected were entered and analyzed using statistical package for the social sciences (SPSS) version 23 software. Quantitative variables were summarized by mean and standard deviation and qualitative variables were presented in frequency tables. Ethical principles were respected throughout this study. Anonymity and confidentiality of the data collected were strictly respected.

\section{RESULTS}

The average age of the women was $25.23 \pm 4.54$ years. The majority $63.6 \%$ of nulliparous women came from the health area of Ibanda, (65.3\%) from academics, $90.3 \%$ from single people, $45.4 \%$ from Catholics followed by Protestants in $42.7 \%$ and $44.2 \%$ of overweight women (Table 1).

Table 1: General characteristics of nulliparous women.

\begin{tabular}{|ll|}
\hline Variables & $\mathbf{N}(\%)$ \\
\hline Age range (years) & \\
\hline $20-25$ & $247(60.0)$ \\
\hline $26-30$ & $112(27.2)$ \\
\hline $31-35$ & $53(12.9)$ \\
\hline Mean \pm standard deviation & $25.23 \pm 4.54$ \\
\hline Place of residence & \\
\hline Kadutu & $33(8.0)$ \\
\hline Ibanda & $262(63.6)$ \\
\hline Out of town & $103(25.0)$ \\
\hline Bagira & $14(3.4)$ \\
\hline Education status & \\
\hline Primary & $6(1.5)$ \\
\hline Secondary & $137(33.2)$ \\
\hline
\end{tabular}




\begin{tabular}{|ll|}
\hline Variables & $\mathbf{N}(\%)$ \\
\hline University & $269(65.3)$ \\
\hline Civil status & \\
\hline Single & $372(90.3)$ \\
\hline Married & $40(9.7)$ \\
\hline Socioeconomic level & $5(1.2)$ \\
\hline Low & $401(97.3)$ \\
\hline Average & $6(1.5)$ \\
\hline Hight & \\
\hline Religion & $187(45.4)$ \\
\hline Catholic & $14(3.4)$ \\
\hline Muslim & $176(42.7)$ \\
\hline Protestant & $35(8.5)$ \\
\hline Others & \\
\hline Body mass index & $3(0.7)$ \\
\hline Lean $(<18.5)$ & $195(47.3)$ \\
\hline Normal $(18.5-24.9)$ & $182(44.2)$ \\
\hline Overweight $(25-29.9)$ & $30(7.3)$ \\
\hline Moderate obsesity $(30-34.9)$ & $2(0.5)$ \\
\hline Morbid obesity $(>40)$ & \\
\hline Age of menarch & $11.83 \pm 1.48$ \\
\hline Mean \pm standard deviation & \\
\hline
\end{tabular}

Table 2: Diet of nulligest women, clothing, use of lightening products and sun exposure.

\begin{tabular}{|ll|}
\hline Variables & N $(\%)$ \\
\hline Diet & $317(76.9)$ \\
\hline Red meat consumption & $289(70.1)$ \\
\hline Green vegetable consumption & $140(34.0)$ \\
\hline Dairy products & $223(54.1)$ \\
\hline Alcohol consumption & $174(42.2)$ \\
\hline Fish consumption & $71(17.2)$ \\
\hline Egg consumption & \\
\hline Dress code & $260(63.1)$ \\
\hline Partially hedged & $143(34.7)$ \\
\hline Fully hedged & $9(2.2)$ \\
\hline Equipped clothing & $358(86.4)$ \\
\hline Time of exposure to the sun (hour) & \\
\hline$<1$ & $54(13.1)$ \\
\hline$>1$ & $242(58.7)$ \\
\hline Use of lightening products & $170(41.3)$ \\
\hline No & \\
\hline Yes & $132(32.0)$ \\
\hline Body complexion & $152(36.9)$ \\
\hline Black & $128(31.1)$ \\
\hline Clear & \\
\hline Dark black &
\end{tabular}

Among the foods consumed by women, red meat comes first, followed by green vegetables and alcohol. In terms of clothing, $63.1 \%$ of women wore partially covered clothing and $34.7 \%$ wore fully covered clothing. The majority of women were exposed to the sun for less than one hour. It appears that $41.3 \%$ of women use skin- lightening products. Body complexion was clear in $36.9 \%$ of women (Table 2). We note that 318 nulligest women (77.2\%) were vitamin D deficient. The serum level was (20 to $29 \mathrm{ng} / \mathrm{dl})$ in $45.9 \%$ of cases and $(<20 \mathrm{ng} / \mathrm{dl})$ in $31.3 \%$ (Table 3).

Table 3: Distribution of nulligest women by serum vitamin D level.

\begin{tabular}{|ll|}
\hline Variables & N $(\%)$ \\
\hline Serum vitamin D level (ng/dl) & \\
\hline Deficiency $(<20)$ & $129(31.3)$ \\
\hline Insufficiency (20-29) & $189(45.9)$ \\
\hline Normal (30-100) & $94(22.8)$ \\
\hline Deficiency in vitamin D & \\
\hline Yes & $318(77.2)$ \\
\hline No & $94(22.8)$ \\
\hline
\end{tabular}

\section{DISCUSSION}

In our study in Panzi Hospital, we found that serum vitamin D levels were $77.2 \%$ defined as vitamin D deficiency among nulligest women screened in Panzi. The serum level found in Panzi was higher in young women aged 20 to 35 years than in other series. Our results are not consistent with those found in the series conducted in Western countries, which found that $40 \%$ of the population over 50 years of age had vitamin D deficiency. ${ }^{1,3}$ Our results are consistent with those found in a European study that showed that $80 \%$ of older people had levels of $25(\mathrm{OH})$ D below $30 \mathrm{ng} / \mathrm{ml}$, Sonja in her series found a prevalence of $82.5 \%$ and Foray in 2012 found a prevalence of $86.9 \%{ }^{2,3}$ The serum level found in the Panzi series is much higher in a young population while in other series; this rate is higher in the population over 50 years old. This shows 
that vitamin $\mathrm{D}$ deficiency is a real public health problem in our environment and that it exposes these women to develop uterine myomas and other pathologies. The results of our study differ from those found in the French series which found that the percentage of people with severe deficiency with levels of $25(\mathrm{OH}) \mathrm{D}$ was below $8 \mathrm{ng} / \mathrm{ml}$ (20 nmol/l) goes from $7 \%$ on the French Riviera to $29 \%$ in the North. 3,4

In our study, we noted that $44.2 \%$ of the women were overweight. These results do not agree with those found by Annabelle who noted only seven (5.7\%) obese subjects. ${ }^{2}$ In our series, almost half of the women were overweight, which could be explained by the dietary changes observed today in the city of Bukavu.

In our study in Panzi Hospital, we found that $34.7 \%$ of women wore fully covered clothing. These results differ from those of Annabelle, who found that only two subjects wore covering clothes and both were deficient $(1.6 \%){ }^{2}$ This difference can be explained by the religious beliefs that dominate in Africa.

We also found in our series that the time of sun exposure was less than one hour in the majority of women. Fortyone percent of the women used skin-lightening products. These results are contrary to those found in the literature, which shows that daily sun exposure should therefore be more prolonged, more in dark-skinned individuals, to meet vitamin D requirements. ${ }^{7,8}$ Dermal synthesis of vitamin D is different depending on skin color and the use of skin lightening products. Since vitamin D is shown to come primarily from the skin, it has been shown that approximately more than one hour of sun exposure each day should be sufficient to meet the vitamin D needs of adults. ${ }^{1,2}$

In our series, body complexion was clear in $36.9 \%$ of women. These results are not the same as those found by Annabelle, this would be explained by the fact that in this study, all the participating subjects had a fair skin tone contrary to our Panzi series. ${ }^{2}$

\section{Limitations}

At this stage, the study did not identify the real impact of vitamin D deficiency on maternal and neonatal outcomes. Further hormonal analyses are needed.

\section{CONCLUSION}

At the end of this study, we found that the serum vitamin D level was $77.2 \%$ too high, defining vitamin D deficiency among nulliparous women in our community. We noted that almost half of the women were overweight. Among the foods consumed by the women, red meat came first, followed by green vegetables and alcohol intake. We noted that $63.1 \%$ of the women wore partially covered clothing and $34.7 \%$ wore completely covered clothing. The time of exposure to the sun was less than one hour for the majority of women. It emerged that $41.3 \%$ of the women used skinlightening products. Body complexion was clear in $36.9 \%$ of women.

Funding: No funding sources

Conflict of interest: None declared

Ethical approval: The study was approved by the Institutional Ethics Committee

\section{REFERENCES}

1. Belaid S, Martin A, Schott AM, Laville M, Le Goaziou MF. La carence en vitamine D chez la femme de 18 à 49 ans portant des vêtements couvrants, une réalité méconnue en médecine générale. La Presse Médicale. 2008;37(2):201-6.

2. Foray AR. Etude de prévalence de la carence en vitamine D chez des sujets adultes sains de 18a 50 ans en Haute Savoie. 2012.

3. Laurent BC. Les carences et insuffisantes en vitamine Dn: une situation largement répandue, des mesures préventives à mettre en place. La Presse médicale. 1983;37(2):187-90.

4. Belaid S, Martin A, Schott AM, Laville M, Le Goaziou MF. La carence en vitamine D chez la femme de 18 à 49 ans portant des vêtements couvrants, une réalité méconnue en médecine générale. La presse médicale. 2008;37(2):201-6.

5. Le Goaziou MF, Dupraz C, Martin A, Martinand N, Quinault P, Schott AM, Contardo GL. Hypovitaminose D chez les femmes jeunes: une réalité sous-estimée. Cahiers de nutrition et de diététique. 2009;44(6):264-72.

6. De Cock C, Bruyere O, Collette J, Reginster JY. Vitamin D inadequacy in French osteoporotic and osteopenic women. Joint Bone Spine. 2008;75(5):567-72.

7. Riah L, Naitkhachat A, Lmidmani F, El Fatimi A, Tahiri A. Déficit en vitamine D chez la femme voilée: enquête dans la région du grand Casablanca. In Annales d'Endocrinologie. Elsevier Masson. 2014;75(5-6):348.

8. Briot K, Audran M, Cortet B, Fardellone P, Marcelli $\mathrm{C}$, Orcel P, et al. Vitamine D: effet osseux et extraosseux ; recommandations de bon usage. La Presse Médicale. 2009;38(1):43-54.

Cite this article as: Balungwe $S$, Maroyi R, Joyeux M, Omari M, Philémon M, Olivier N. Seric status of vitamin $\mathrm{D}$ among nulligest women at the general reference hospital of Panzi in Democratic Republic of the Congo. Int J Reprod Contracept Obstet Gynecol 2021;10:1963-6. 